Short communication

\title{
Annual flowering of Dendrocalamus longispathus (Kurz) Kurz in Mizoram
}

\author{
Sandeep Yadav*, Hans Raj and Lalnunmawia \\ Forest Research Centre - Bamboo and Rattan, Aizawl-796007, Mizoram, India \\ *Corresponding Author: sandeep080987@gmail.com \\ [Accepted: 10 March 2019] \\ [Cite as: Yadav S, Raj H \& Lalnunmawia (2019) Annual flowering of Dendrocalamus longispathus (Kurz) Kurz \\ in Mizoram. Tropical Plant Research 6(1): 46-48]
}

\section{INTRODUCTION}

Bamboo belongs to the Poaceae family and it has about 90 genera with over 1200 species distributed all over the world (Lobovikov et al. 2007). It is naturally distributed in the tropical and subtropical belt between approximately $46^{\circ}$ north and $47^{\circ}$ south latitude, and is commonly found in Africa, Asia and Central and South America. There are few species which can grow in temperate zones also such as Arundinaria gigantean (Walter) Muhl. Among asian countries, India and China are the two major bamboo producing countries (Maxim et al. 2005).

The bamboo bearing area in India is estimated to 15.69 million hectares (Anonymous 2017). There are about 125 indigenous and 11 exotic species of bamboo belonging to 23 genera reportedly found in India (Anonymous 2017). About $66 \%$ of the growing stock is concentrated in the North Eastern states of the country (Adkoli 2002). The principal bamboo genera occurring in India are Arundinaria, Bambusa, Chimonobambusa, Dendrocalamus, Dinochola, Gigantochloa etc.

Mizoram is situated in the north eastern part of India, and it shares international borders with Bangladesh in the west and Myanmar in east and south. The geographical area of the state is $21,081 \mathrm{~km}^{2}$ which constitutes $0.64 \%$ of the total area of the country. The recorded forest cover in the state is $18,186 \mathrm{~km}^{2}$ which works out to be $86.27 \%$ of its geographical area (Anonymous 2017). The extent of bamboo bearing area in the forests of the state is $3,267 \mathrm{~km}^{2}$ (Anonymous 2017). A number of bamboo species grow very luxuriantly in the state, most notably is the Melacanna beccifera (Roxb.) Kurz, which constitutes approximately $70 \%$ of the bamboo cover. Dendrocalamus longispathus (Kurz) Kurz, D. hamiltonii Gamble, D. strictus (Roxb.) Nees and Bambusa tulda Roxb. are the other notable bamboo species of the state having populations distributed in small patches across the state.

Dendrocalamus longispathus is a large caespitose bamboo; culms up to $20 \mathrm{~m}$ tall, up to $10 \mathrm{~cm}$ in diameter; nodes swollen; internode swollen, $25-60 \mathrm{~cm}$ long. It occurs in moist hill slopes and along streams in the moist fertile loamy soil and particularly shaded fringes of the forest cover. It is distributed in India (Assam, Manipur, Mizoram and Tripura), Bangladesh and Myanmar. It is called as Rawnal in Mizo language. Mature culms are harvested for its use as construction material and tender shoots are harvested during rainy season for local consumption. Apart from these two most common uses, it is also being utilized for handicraft industries, mats, and matply industries. To sum up, it can be argued that after Melocanna baccifera (Roxb.) Kurz, it is the second most utilized bamboo to sustain rural livelihood of the state.

According to Gamble (1896), D. longispathus flowered during 1876 and 1879-80 in Chittagong (Bangladesh) and during 1871 and 1891 in Myanmar. Gupta (1972) reported it in flowering from Assam in 1968 and in Mizoram during 1966-67. Bahadur (1979) stated that it was flowering in Forest Research Institute, Dehradun in 1979. Sharma et al. (2014) reported its sporadic flowering in Kolasib and Mamit districts of Mizoram.

In this present communication, it is reported that since 2014, small and segregated populations of this species flower annually across the state (Table 1). Flowering and non-flowering clumps can be found within the same site (Fig. 1). Few individual in the same population did not flowered at all. This peculiar flowering pattern of D. longispathus is a cause of concern for all those who are associated with it. Localized arid conditions can 
be one of the factors triggering flowering. Usually this species is present in gradually sloping hills where few natural water sources are present at some places. There is a very less rainfall in Mizoram from October till March. The observed sporadic and segregated flowering pattern is may be due to localized unavailability of water. Aftermath of flowering in D. longispathus includes death of flowering culms and increase in rodent population. Since jhumming or slash and burn practice is quite prevalent in Mizoram, therefore, dead flowering clumps are very susceptible to fire.

Table 1. Flowering in Dendrocalamus longispathus (Kurz) Kurz in Mizoram since 2014.

\begin{tabular}{|c|c|c|c|c|}
\hline S.N. & Year & Month of flowering & Place of flowering & Remarks \\
\hline 1. & 2014 & October-November & Kolasib and Mamit district & Clumps died after \\
\hline 2. & 2015 & October-December & $\begin{array}{l}\text { Kolasib, Mamit, and Sercchip } \\
\text { district }\end{array}$ & $\begin{array}{l}\text { flowering and seed setting. } \\
\text { Population of wild rodents }\end{array}$ \\
\hline 3. & 2016 & October-November & $\begin{array}{l}\text { Lengpui, Aizawl and lunglei } \\
\text { district }\end{array}$ & $\begin{array}{l}\text { and other small mammals } \\
\text { increased due to the }\end{array}$ \\
\hline 4. & 2017 & October-November & $\begin{array}{l}\text { Lengte, Lawngtlai, Siaha and } \\
\text { Mamit district }\end{array}$ & $\begin{array}{l}\text { abundant availability of } \\
\text { bamboo seeds. }\end{array}$ \\
\hline 5. & 2018 & October-November & Lengpui, Sercchip, Kolasib, Mamit & \\
\hline
\end{tabular}
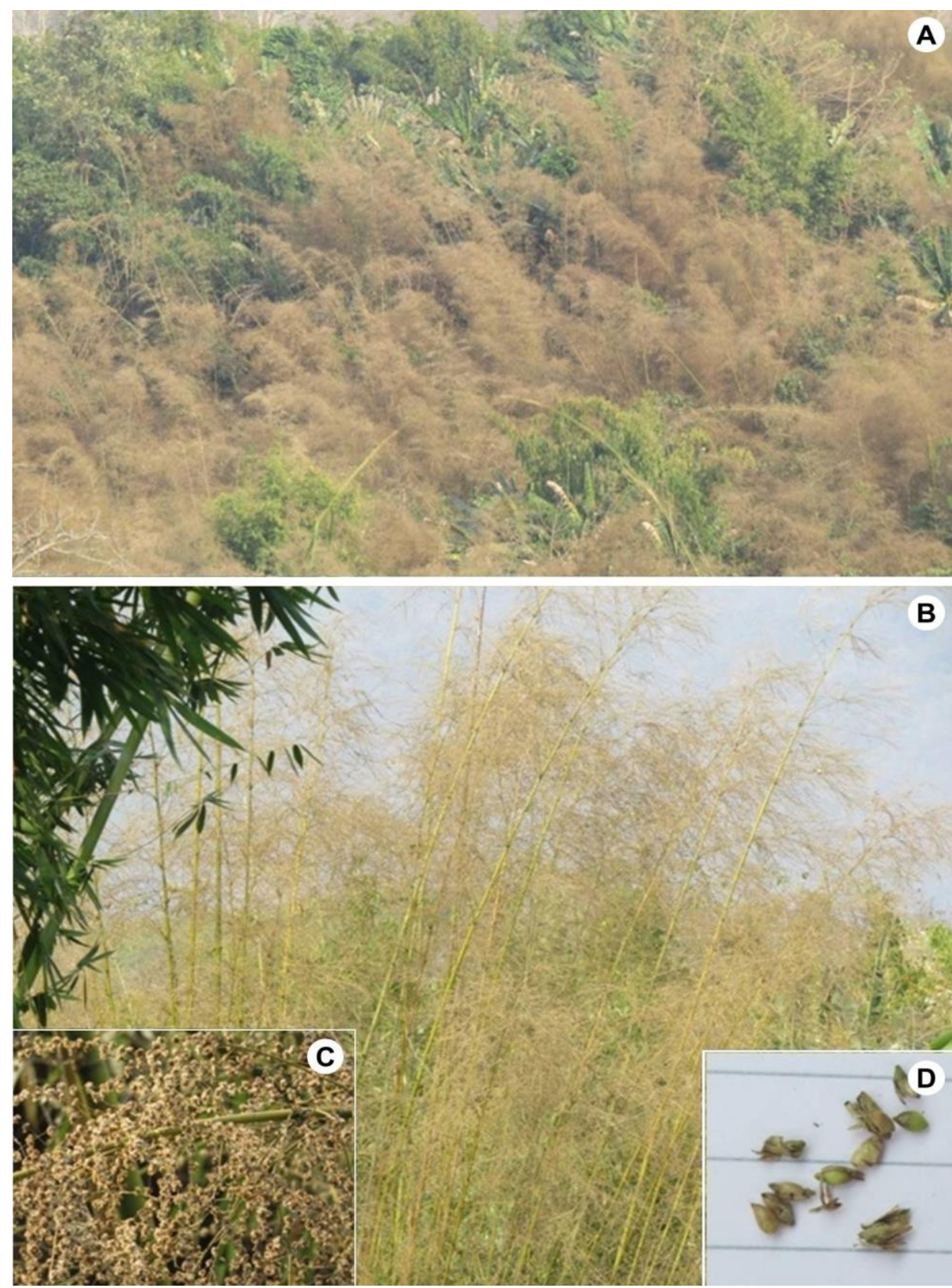

Figure 1. Dendrocalamus longispathus (Kurz) Kurz: A, Flowering population, Mizoram in 2017 (Note the non-flowering green clumps amongst flowering brown clumps); B, Individual clump in flowering stage; C, Inflorescence; D, Immature seeds. 


\section{REFERENCES}

Anonymous (2017) India State Forest Report. Forest Survey of India, Dehradun, India.

Adkoli NS (2002) Indian bamboos in early $21^{\text {st }}$ century In: Kumar A, Ramanuja Rao IV \& Sastry CB (eds) Bamboo for sustainable Development. VSP and INBAR, pp. 17-25.

Bahadur KN (1979) Taxonomy of Bamboos. Indian Journal of Forestry 2(3): 222-240.

Gamble JS (1896) The Bambuseae of British India. Annals of Royal Botanic Garden, Calcutta 7: 1-133.

Gupta KK (1972) Flowering of different species of Bamboos in Cachar district of Assam in recent times. Indian Forester 98: 83-85.

Lobovikov M, Paudei S, Piazza M, Ren H \& Wu J (2007) World bamboo resources: A thematic study prepared in the framework of the Global Forest Resources Assessment 2005. FOA, Rome.

Maxim L, Paudel S, Piazza M, Ren H \& Wu J (2005) World Bamboo Resources: A thematic study prepared in the framework of the Global Forest Resources Assessment. Food and Agriculture Organization, Italy, 73 p.

Sharma HR, Yadav S, Deka B, Meena RK \& Bisht NS (2014) Sporadic flowering of Dendrocalamus longispathus (Kurz) Kurz in Mizoram, India. Tropical Plant Research 1(1): 26-27. 